\title{
Efektifitas Metode Kontrasepsi Jangka Panjang (MKJP) dalam Mencegah Kehamilan Dini: Kajian Deskriptif di Puskesmas Sasi Kota Kefamenanu
}

\author{
Pilomena Redo ${ }^{* 1}$ \\ ${ }^{1}$ Dinas Pengendalian Penduduk dan Keluarga Berencana, Kabupaten Timor Tengah Utara, Propinsi \\ Nusa Tenggara Timur, Indonesia \\ Email: ${ }^{1}$ menaredo10@gmail.com
}

\begin{abstract}
Abstrak
Penelitian ini bertujuan untuk mengetahui efektifitas jenis MKJP yang dipakai oleh akseptor KB aktif dalam mencegah kehamilan dini di Puskesmas Sasi Kota Kefamenanu. Manfaat yang didapatkan dalam penelitian ini diharapkan menjadi acuan, sumbangan pikiran dan bahan masukan bagi para akseptor KB aktif di Puskesmas Sasi Kota Kefamenanu serta berbagai unsur dinas terkait lainnya dalam mengembangkan metode kontrasepsi yang lebih tepat guna. Adapun metode yang digunakan dalam penelitian ini yakni kajian dekriptif kualitatif dengan teknik pengambilan data menggunakan teknik observasi, dokumentasi, mencatat dan melakukan wawancara. Objek penelitian ini adalah efektifitas jenis MKJP yang dipakai oleh akseptor KB aktif dalam mencegahan kehamilan dini dan teknik penentuan subjek menggunakan cara purposive sampling yang dipilih berdasarkan pertimbangan tertentu. Jumlah informan dalam penelitian ini sebanyak tujuh belas orang yang merupakan akseptor KB aktif di Puskesmas Sasi dengan kriteria yang telah ditentukan terdahulu. Teknik analisis data dilakukan dengan cara mereduksi data, menyajikan data dan melakukan verifikasi dan penarikan kesimpulan. Hasil dari penelitian ini membuktikan bahwa penggunaan MKJP oleh akseptor KB aktif di Puskesmas Sasi terdiri dari metode suntikan, pil KB, implan, IUD dinilai efektif dalam mencegah kehamilan dini karena cara kerja setiap metode adalah untuk mengurangi fertilisasi atau kesuburan dan mengahalangi terjadinya pembuahan pada rahim wanita dengan tingkat kerja yang berbeda-beda pada setiap metode.
\end{abstract}

Kata kunci: Efektifitas, Kehamilan Dini, MKJP

\begin{abstract}
This study aims to determine the effectiveness of the type of MKJP used by active family planning acceptors in preventing early pregnancy at Sasi Health Center, Kefamenanu City. The benefits obtained in this study are expected to be a reference, the contribution of ideas, and input for active family planning acceptors at the Sasi Health Center, Kefamenanu City, and various other related elements of the agency in developing more effective contraceptive methods. The method used in this study is a qualitative descriptive study with data collection techniques using observation, documentation, recording, and interviewing techniques. The object of this research is the effectiveness of the type of MKJP used by active family planning acceptors in preventing early pregnancy and the technique of determining the subject using purposive sampling which is selected based on certain considerations. The number of informants in this study was seventeen people who were active family planning acceptors at the Sasi Health Center with predetermined criteria. Data analysis techniques are carried out by reducing data, presenting data, and verifying and drawing conclusions. The results of this study prove that the use of MKJP by active family planning acceptors at the Sasi Health Center consists of injection methods, birth control pills, implants, IUDs are considered effective in preventing early pregnancy because the way each method works is to reduce fertilization or fertility and prevent fertilization in a woman's uterus. with different levels of work on each method.
\end{abstract}

Keywords: Early Pregnancy, Effectiveness, MKJP

\section{PENDAHULUAN}

Upaya pemerintah Indonesia dalam menekan angka kelahiran dan pertambahan jumlah penduduk merupakan wujud perhatian pemerintah dalam meningkatkan kesejahteraan keluarga. Berbagai upaya telah dilakukan namun, kesenjangan antara program pemerintah dalam menekan angka kelahiran 
dengan pertambahan jumlah penduduk semakin meluas. Mengacu pada data statistik tiga tahun terakhir yakni tahun 2019 sampai tahun 2021 (Nugraheny, 2020) bahwa pertumbuhan penduduk Indonesia mengalami peningkatan yang signifikan. Pada tahun 2019 mencapai 266,91 juta jiwa, tahun 2020 mencapai 268,58 juta jiwa dan berdasarkan data administrasi kependudukan (Adminduk) pada bulan Juni 2021 pertumbuhan penduduk Indonesia mencapai 272.229.372 jiwa (Dukcapil, 2021). Pertambahan jumlah penduduk rata-rata mencapai $0,71 \%-0,82 \%$. Hal ini menunjukkan ketidak seimbangan antara jumlah pertambahan penduduk dengan angka kelahiran yang dapat mempengaruhi kualitas sumber daya manusia sehingga salah satu cara yang ditempuh pemerintah adalah dengan melakukan gebrakan Keluarga Berencana (KB) yang diprogramkan setiap tahun. Program KB Nasional secara umum dilakukan untuk membentuk sebuah keluarga kecil sejahtera sebagai fondasi dalam terbentuknya masyarakat yang adil, makmur dan sejahtera melalui penekanan angka kelahiran anak dan pertumbuhan masyarakat. Salah satu wujud implementasi dari program-program BKKBN atau yang lebih dikenal sekarang Dinas Pengendalian Penduduk dan Keluarga Berencana (DP2KB) adalah pembangunan keluarga berencana nasional yang bertujuan untuk membentuk keluarga yang berkualitas yakni lahirnya generasi sehat secara jasmani dan rohani, sejahtera dan berwawasan yang luas, terpenuhinya hak-hak reproduksinya, dan bertaqwa kepada Tuhan Yang Maha Esa (Farina \& Susilowati, 2017).

Bentuk pelayanan kesehatan bagi para pasangan usia subur (PASUTRI) dapat dilakukan dengan pemilihan metode kontrasepsi yang terdiri dari dua jenis yakni Metode Kontrasepsi Jangka Panjang (MKJP) dan metode non-MKJP. Dari kedua metode tersebut, pemerintah lebih menyarankan kepada masyarakat agar menggunakan MKJP dibandingkan dengan non MKJP karena program non-MKJP tidak efektif sedangkan program MKJP dinilai lebih efektif jika dilihat dari tingkat kegagalan dan komplikasinya lebih kecil (Aldila \& Damayanti, 2019). Program pemerintah tersebut merupakan salah satu cara untuk memperkecil jumlah kematian ibu terutama yang mengalami kondisi usia muda dalam melahirkan, sering melahirkan, tidak ada jarak kelahiran, dan terlalu tua untuk melahirkan. Dalam memilih metode KB merupakan keputusan akhir seorang akseptor KB sebelum menggunakannya sehingga setiap keputusan menjadi rujukan untuk mencegah terjadinya kehamilan dini. Program KB yang dicanangkan pemerintah pusat pun ditindaklanjuti sampai pada tingkat daerah, dan salah satu sarana kesehatan yang mendukung program KB adalah Puskesmas Sasi Kota Kefamenanu.

Mengacu pada uraian di atas, peneliti tertarik untuk melakukan sebuah kajian deskriptif tentang bagaimanakah keefektifan jenis metode kontrasepsi jangka panjang (MKJP) yang dipakai oleh akseptor KB aktif dalam mencegah kehamilan dini di Puskesmas Sasi Kota Kefamenanu? Tujuan dalam penelitian ini untuk mengetahui efektifitas jenis MKJP yang dipakai oleh akseptor KB aktif dalam mencegah kehamilan dini di Puskesmas Sasi Kota Kefamenanu. Manfaat penelitian ini diharapkan menjadi acuan, sumbangan pikiran dan bahan masukan bagi para akseptor KB aktif di Puskesmas Sasi Kota Kefamenanu serta berbagai unsur dinas terkait lainnya dalam mengembangkan metode kontrasepsi yang lebih tepat guna.

\subsection{Keluarga Berencana (KB)}

Salah satu program pemerintah yang digencarkan saat ini adalah termasuk keluarga berencana karena tujuan dari program ini adalah menyetarakan kebutuhan pokok dengan realita pertambahan jumlah penduduk yang tidak seimbang. Selain tujuan tersebut program ini juga bertujuan untuk membentuk masyarakat yang sejahtera dengan kegiatan-kegiatan dalam mengkampanyekan penggunaan dan pelayanan serta pemanfaatan alat kontrasepsi.

Menurut Budioro dalam (Susanti et al., 2020) kegiatan yang utama dari keluarga berencana adalah memberi penyuluhan dan pelayanan tentang alat kontrasepsi. Kontrasepsi mengandung arti bahwa penggunaan alat atau metode yang berkaitan dengan pengaturan kehamilan yang bertujuan untuk mencegah kehamilan. Penggunaan kontrasepsi dengan tujuan lain adalah mengatur jarak kehamilan, menunda kehamilan dan mengurangi kesuburan kandungan. Program Keluarga Berencana (KB) dikatakan berhasil apabila didukung dengan ilmu pengetahuan yang memadai, dan sikap atau tingkah laku serta budaya dari diri seorang akseptor KB itu sendiri (Ari \& Trisnawati, 2016). Seorang akseptor KB sebelum memilih jenis akseptor yang akan dipakai terlebih dahulu harus bisa memahami atau 
mengetahui keunggulan dan kekurangan dari pemakaian kontrasepsi sehingga tidak menimbulkan permasalahan dikemudian hari.

Salah satu program pemerintah untuk menekan jumlah dan jarak anak ideal atau yang diinginkan dalam sebuah rumah tangga dilakukan melalui program KB. Ada berbagai cara pencegahan kehamilan dini yang diprogramkan dalam KB namun, pada kenyataannya belum maksimal dalam penggunaanya karena berbagai kendala yang dihadapi, antara lain kurangnya pemahaman dasar tentang alat kontrasepsi $\mathrm{KB}$, sosial ekonomi masyarakat yang rendah, adat istiadat, norma dan keyakinan, status sosial perempuan dalam keluarga dan berbagai faktor eksternal maupun internal lainnya yang turut memengaruhi pencapaian efektifitas program KB di Indonesia.

\subsection{Jenis Metode Kontrasepsi}

Ada beberapa jenis alat kontrasepsi yang diprogramkan oleh pemerintah dalam mencanangkan program KB yang dapat digunakan oleh calon akseptor KB aktif. Metode-metode yang seringkali dikampanyekan, antara lain Metode Kontrasepsi Jangka Panjang (MKJP) seperti Alat Kontrasepsi Dalam Rahim (AKDR), Alat kontrasepsi bawah kulit (AKBK) dan kontrasepsi mantap seperti vasektomi (MOP) dan tubektomi (MOW) (Ernawati, 2016). Pemilihan metode kontrasepsi oleh seorang akseptor KB menjadi hal penting dalam melanjutkan program KB yang telah disetujui oleh PASUTRI. MKJP diartikan sebagai metode kontrasepsi yang memiliki daya guna yang cukup baik dalam mencegah kehamilan dini jika dibandingkan dengan metode non MKJP.

Menurut Manuaba dalam (Rendys et al., 2017) bahwa ada dua jenis metode kontrasepsi yang sering digunakan oleh akseptor KB yakni non MKJP dan MKJP. Yang termasuk dalam metode non MKJP atau metode sederhana dapat dilakukan tanpa alat atau jika menggunakan alat dapat berupa kondom, sedangkan yang termasuk dalam MKJP antara lain, IUD, implan, MOW dan MOP, suntik, dan pil. Kedua jenis metode kontrasepsi semata-mata digunakan untuk mencegah kehamilan dini atau menunda usia kehamilan dan jarak lahir anak yang pada akhirnya berdampak pada peningkatan kesejahteraan keluarga. Metode MKJP sering disebut sebagai metode modern seperti implan, IUD (intra uterine device), metode operasi wanita, metode operasi pria, sedangkan metode non MKJP atau metode sederhana seperti, penggunaan kondom, menghitung masa subur wanita, dan penundaan kehamilan secara alamiah (Weni et al., 2019).

Kesiapan seorang akseptor dalam memilih metode kontrasepsi KB tidak terlepas dari dukungan keluarga dalam hal ini PASUTRI. Seorang suami/isteri sangat berperan dalam penentuan metode yang akan digunakan karena efek dari penggunaan metode kontrasepsi akan berdampak secara langsung terhadap akseptor KB. Dukungan lain berasal dari mitra kesehatan yang berperan dalam memberikan pelayanan terutama berkaitan dengan pemahaman akseptor tentang metode-metode kontrasepsi yang akan dipakai. Setiap metode yang ditawarkan tentu memiliki pengaruh secara positif maupun negatif tergantung dari kecocokan masing-masing calon akseptor karena pengaruh atau efek positif maupun negatif dirasakan atau dialami secara langsung oleh akseptornya. Menurut (Aryati et al., 2019) bahwa dalam meningkatkan peran serta calon akseptor usia subur dengan menggunakan metode MKJP yang memiliki dampak positif dalam menurunkan angka kelahiran anak secara nasional. Kelebihan dari MKJP adalah mengurangi fertilitas atau kesuburan seorang wanita. Pendapat lain dikemukakan oleh (Wulandari et al., 2016) bahwa MKJP merupakan metode kontrasepsi yang dapat digunakan dalam kurun waktu panjang > 2 tahun dengan tujuan mengatur jarak kelahiran anak di atas 3 tahun secara efektif dan efisien pada pasangan usia subur yang belum menginginkan keturunan.

Metode non MKJP memiliki juga dampak negatif bagi akseptor KB, karena metode non MKJP seperti kondom memiliki tingkat kefektifan sangat rendah dibanding dengan metode MKJP. Metode MKJP beresiko terhadap diri calon akseptor KB seperti efek suntik dapat menaikan berat badan dengan cepat, kemungkinan terdapat bercak darah, terhentinya siklus haid tidak normal yang disebabkan oleh ketidakseimbangan hormon dalam diri akseptor sehingga menimbulkan perubahan kekeringan pada selaput lendir (Sari et al., 2018). Seorang akseptor aktif dalam memilih metode kontrasepsi tentu memikirkan segala resiko yang akan timbul baik pada metode modern maupun metode sederhana. Metode modern atau MKJP memiliki tingkat kefektifan lebih tinggi dibandingkan dengan metode non MKJP atau metode sederhana namun, efek samping dari penggunaan MKJP cukup beresiko seperti 
bertambahnya berat badan, pendarahan, dan penyakit lain yang dapat muncul akibat ketidak cocokan dalam penggunaan metode MKJP tersebut. Metode non MKJP atau metode sederhana seperti senggama terputus, pantang berkala, kondom, diafragma atau cup, cream, jelly sangat ditentukan oleh ketelitian dan kehati-hatian akseptor ketika memilih menggunakannya, karena metode sederhana yang sering digunakan sangat kecil pengaruhnya terhadap penyakit namun beresiko tinggi terhadap kehamilan dini.

\subsection{Faktor-Faktor Yang Memengaruhi Pemilihan MKJP}

Dalam menjalankan program MKJP masih muncul hambatan-hambatan secara eksternal seperti lemahnya institusi daerah dalam pelaksanaan kampanye KB terutama berkaitan dengan ketersediaan tenaga medis dalam pelayanan kesehatan, serta berbagai faktor internal lainnya yang turut mempengaruhi seorang akseptor dalam memilih alat kontrasepsi yang diinginkan, antara lain: tingkat pendidikan akseptor, lemahnya tingkat pendapatan masyarakat, patokan harga pelayanan kesehatan, minimnya pengetahuan alat kontrasepsi oleh PASUTRI, pola hidup atau tradisi masyarakat (Nasution \& Naibaho, 2018).

Menurut Notoatmodjo dalam (Budiarti et al., 2017) bahwa terdapat beberapa faktor yang berkaitan dengan pemilihan MKJP antara lain 1). faktor presdisposisi yaitu faktor dasar yang memudahkan berlakunya suatu perilaku tertentu dalam diri seorang akseptor seperti kognitif, tingkah laku, norma, keimanan, usia dan faktor lainnya di luar diri pribadi akseptor seperti jumlah anak, sosial ekonomi, dan lingkungan masyarakat, 2). faktor yang memungkinkan terjadinya tindakan akseptor yang dikategorikan sebagai faktor pendukung seperti fasilitas kesehatan seperti rumah sakit, puskesmas, posyandu, alat-alat kontrasepsi serta obat-obatan yang menjamin keselamatan diri dari seorang akseptor, dan 3). faktor penguat yakni faktor motivasi yang berperan dalam memberikaan dukungan secara moril terhadap perilaku akseptor. Faktor penguat dapat diperoleh dari dukungan suami/isteri, teman, keluarga, dan peran petugas kesehatan. Dari pendapat di atas dapat dikatakan bahwa ada beberapa faktor yang turut berpengaruh pada pemilihan MKJP oleh seorang calon akseptor $\mathrm{KB}$, antara lain faktor pengetahuan, tingkat pendidikan, usia, paritas, kesehatan, keuangan, metode kontrasepsi yang dipilih serta efek yang timbul dari pemakaian alat kontrasepsinya.

\subsection{Kehamilan Dini}

Kehamilan akan dialami oleh semua wanita di seluruh dunia. Terjadinya peristiwa kehamilan karena adanya pertemuan antara sel sperma dengan sel telur sehingga menyebabkan pembuahan dalam rahim seorang ibu. Kehamilan dini juga sering dialami pasangan suami istri yang tidak mengatur jarak kelahiran anak, dan dapat juga terjadi karena akibat tidak menggunakan alat kontrasepsi KB oleh pasangan suami istri. Kehamilan dini yang sering terjadi saat ini karena adanya hubungan seks oleh lakilaki dengan perempuan yang belum siap secara umur serta kurangnya pemahaman akan masa subur wanita dan kurangnya pengetahuan yang berkaitan dengan penggunaan alat-alat kontrasepsi. Pendapat Cholil yang dikutip oleh (Purwanti \& Trisnawati, 2016) bahwa kehamilan normal pada seorang wanita menggunakan rumus 3-3-35 yakni jumlah anak yang dilahirkan dalam sebuah keluarga adalah 3 orang, jumlah melahirkan anak sebaiknya 3 kali persalinan, dan umur yang tepat untuk seorang wanita melahirkan maksimal 35 tahun. Kehamilan yang pertama dan selanjutnya memiliki resiko yang hampir sama, sehingga sangat dibutuhkan perhatian dan perawatan maksimal terhadap kesehatan ibu dan anak. Perencanaan berkelanjutan dalam mengurangi resiko kehamilan selanjutnya adalah den gan menerapkan program KB. Pendapat lain dikemukakan juga oleh (Laili \& Masruroh, 2018) bahwa jarak kehamilan yang dekat pada seorang wanita melahirkan dapat beresiko terhadap terjadinya penyakit penyerta seperti perdarahan, kurang darah (anemia), ketuban pecah sebelum waktunya. Selain itu juga faktor komunikasi keluarga terutama dukungan suami sangat berpengaruh terhadap proses kehamilan bagi seorang wanita, terkadang ada suami yang tidak menginginkan istri menggunakan alat-alat kontrasepsi ideal sehingga dengan mudah terjadinya kehamilan atau tidak ada jarak kehamilan yang tepat.

Ketidaktepatan dalam pemilihan MKJP oleh seorang akseptor dapat menyebabkan terjadinya kehamilan dini. Sebagai contoh, seorang akseptor yang memilih menggunakan pil KB dapat beresiko tinggi mengalami kehamilan dini jika dibandingkan dengan penggunaan MKJP lainnya, karena metode pil KB berpeluang terjadinya kehamilan dini lebih tinggi apabila ada kelalaian akseptor dalam 
mengontrol penggunaan metode pil secara berkala. Penggunaan MKJP lainnya seperti suntikan, Alat Kontrasepsi dalam Rahim (AKDR), Alat Kontrasepsi Bawah Kulit (AKBK), tubektomi untuk mengurangi fertilisasi pada wanita dan vasektomi pada laki-laki. Tujuan utama dari semua jenis MKJP adalah meminimalisir tingkat kehamilan dini karena dapat digunakan dalam jangka waktu yang panjang sehingga mampu menekan angka kelahiran. Kehamilan seorang wanita dikatakan normal apabila jarak persalinan sebelum dan yang akan datang mencapai usia $\geq 2$ tahun. Kurangnya partisipasi seorang akseptor KB dalam memilih metode dapat memberikan pengaruh terjadinya kehamilan dini. Jika seorang aksepor KB memilih menggunakan metode MKJP maka resiko terjadinya kehamilan dini lebih kecil.

\section{METODE PENELITIAN}

Penelitian ini adalah penelitian lapangan dengan menggunakan metode deskriptif kualitatif. Creswell dalam (Sugiyono, 2015) menjelaskan bahwa metode kualitatif adalah metode yang menggambarkan tentang masalah sosial atau masalah kemanusiaan dan menguraikan tentang perilaku setiap individu atau kelompok yang diamati. Dalam penelitian ini, peneliti melakukan teknik pengumpulan data dengan cara: 1). observasi, yaitu peneliti mengamati situasi di lapangan secara langsung berkaitan dengan MKJP di Puskesmas Sasi, 2). dokumentasi, yaitu peneliti melakukan perekaman audio-visual untuk memperoleh data yang valid berkaitan dengan dokumen pendukung MKJP, 3). mencatat, yaitu peneliti melakukan pencatatan yang berkaitan dengan penggunaan jenis MKJP, dan 4). melakukan wawancara, yaitu peneliti melakukan wawancara langsung terhadap para informan untuk memperoleh data yang berkaitan dengan penggunaan MKJP.

Efektifitas jenis MKJP yang dipakai oleh akseptor KB aktif dalam mencegah kehamilan dini dijadikan sebagai objek penelitian. Dalam penentuan informan sebagai subjek penelitian, peneliti menggunakan metode purposive sampling yang dipilih berdasarkan pertimbangan dan tujuan tertentu sehingga data yang dikumpulkan oleh peneliti dapat menjawab fokus penelitian, dikarenakan setiap informan merupakan orang yang paling tahu tentang fokus yang diteliti (Sugiyono, 2017). Kriteria nara sumber dalam penelitian ini sebagai berikut: 1). wanita dewasa yang dinyatakan sebagai akseptor KB aktif minimal 1 tahun terakhir, 2). dapat berkomunikasi menggunakan bahasa Indonesia dengan baik, 3). berkenan memberikan informasi yang akurat, 4). akseptor KB aktif di wilayah kerja Puskesmas Sasi, 5). mengetahui secara baik tentang metode kontrasepsi KB. Rincian data informan sebagai berikut.

Tabel 1. Data Informan Akseptor KB Aktif di Puskesmas Sasi Bulan Januari-September 2021

\begin{tabular}{lccl}
\hline Nama & Usia & $\begin{array}{c}\text { Jenis } \\
\text { KB }\end{array}$ & Alamat \\
\hline Yasinta & 39 & Pil & Upkasen \\
Getrudis & 24 & Implan & Fatuteke \\
Metriana & 31 & Suntik & Benpasi \\
Maria K. & 37 & Suntik & Sasi \\
Veronika & 23 & Implan & Aplasi \\
Lidwina & 27 & Suntik & Sasi \\
Christina & 43 & IUD & BTN \\
Fienelda & 44 & Suntik & Sasi \\
Maria M. & 34 & Suntik & Bois \\
Mersi & 34 & Suntik & Sasi \\
Santi & 30 & Implan & Dalehi \\
Maria B. & 30 & Implan & Noemuti \\
Wasti & 22 & Pil & Sasi \\
Nordiana & 42 & Suntik & Mubeli \\
Dolfiana & 24 & IUD & T.Putih \\
Julia & 39 & Suntik & Upkasen \\
Dafrosa & 36 & Pil & Km.09 \\
\hline
\end{tabular}


Adapun metode yang digunakan dalam menganalisis data penelitian ini yakni interaktif Miles and Huberman. Dalam (Sugiyono, 2015) bahwa terdapat tiga tahapan analisis data pada penelitian kualitatif yakni: 1). reduksi data, yaitu pemilahan data lapangan tentang MKJP yang disesuaikan dengan kebutuhan, 2). penyajian data, yaitu data yang ditampilkan adalah uraian dalam bentuk kata-kata untuk menjelaskan tentang keefektifan jenis MKJP yang dipakai akseptor KB aktif, 3). Penarikan kesimpulan dan verifikasi, yaitu menyimpulkan sementara dan melakukan peninjauan kembali data MKJP di lapangan untuk melengkapi jawaban pada fokus penelitian. Pengujian keabsahan data MKJP di Puskesmas Sasi dilakukan secara objektif dan bisa dipertangungjawabkan.

\section{HASIL DAN PEMBAHASAN}

\subsection{Metode suntikan KB}

Pengertian metode suntik adalah jenis metode modern yang terdiri dari injeksi sebulan sekali dan injeksi tiga bulan sekali. Fungsi dari metode suntik adalah menghambat ovulasi dan mengentalkan lendir serviks sehingga terjadi penghambatan atau terganggu jalannya pembuahan dari sel sperma. Adapun hasil wawancara dengan Ibu Metiana, salah satu akseptor KB aktif di Puskesmas Sasi yang menggunakan metode suntikan KB. Kutipan hasil wawancara sebagai berikut:

"...Saya menggunakan jenis suntik tiga bulan sudah dari tahun 2018 sampai sekarang dan rutin melakukan kontrol suntik. Efek samping tidak dirasakan, kondisi normal, berat badan bertambah. Menurut saya, KB suntik dapat mencegah hamil dini. Jarak anak saya rata-rata 3 tahun, karena itu KB suntik efektif untuk jaga jarak hamil...”

Selain itu, dikatakan pula oleh Ibu Nordiana dalam kutipan hasil wawancara berikut:

“...Saya menggunakan metode suntik tiga bulan sejak anak pertama dan saya melepas suntik dan hamil lalu melahirkan hingga anak keempat. Setelah melahirkan anak keempat saya ikut lagi suntik dari tahun 2018 sampai sekarang. Saya tidak rasa kepala sakit, pusing dan tidak ada perubahan berat badan, dan saya merasa cocok, hanya tidak haid sampai sekarang. Merasa normal tapi tidak haid. Menurut saya jenis KB suntik bisa menunda kehamilan dan berpengaruh jika terlambat suntik namun selama ini saya tidak terlambat suntik..."

Efektifitas metode suntik dalam mencegah kehamilan dini dijelaskan juga oleh Ibu Maria K., dalam kutipan hasil wawancara sebagai berikut:

“...Saya menggunakan KB suntik, dari awal penggunaan namun, saya juga pernah pakai pil karena tidak haid selama pake suntik. Saya juga pernah pasang spiral. Anak pertama saya pakai spiral, karena waktu itu masa 3 tahun dan baru 5 bulan ada gangguan atau efek samping pusing dan pingsan akhirnya saya lepas dan yang cocok dengan saya adalah minum pil dan suntik. Karena efek suntik tidak haid maka saya minum pil untuk melancarkan haid, tapi sekarang posisi saya pake suntik. Dan efek hanya sakit kepala, berat badan bertambah. Menurut saya, menggunakan jenis KB ini tidak mudah hamil, karena lebih efektif walaupun terlambat suntik selama 1 bulan. Kalau tidak haid saya minum pil..."

Selain itu, dijelaskan pula oleh Ibu Lidwina yang menggunakan metode suntik dalam kutipan hasil wawancara berikut:

"...Saya menggunakan KB suntik tiga bulan, dari anak usia 1 tahun. Efek samping penggunaan tidak datang bulan saja, menurut saya suntik lebih efektif dari jenis lain, untuk menunda kehamilan, karena buktinya anak saya sudah berusia 5 tahun. Saya tidak ingin menggunakan metode lain. Saya hanya ingin menggunakan metode suntik saja..."

Hal senada diungkapkan juga oleh Ibu Fienelda yang menggunakan metode suntikan untuk pencegahan kehamilan dini seperti dalam kutipan hasil wawancara berikut:

“...Saya menggunakan metode suntik dari anak satu tahun dan sekarang anak saya sudah kelas satu SMA, kadang saya ganti pil untuk umpan haid, karena efek samping dari suntik itu tidak haid, berat badan bertambah, sakit kepala dan emosi tidak stabil. Menurut saya jenis suntik lebih baik dari jenis KB lainnya dalam mencegah hamil, karena dulu pakai pil saya kecolongan karena harus minum tiap malam dan pada akhirnya saya hamil anak yang terakhir, tapi sekarang saya pake suntik jadi tidak hamil lagi..."

Hasil wawancara dengan Ibu Maria M., yang mengungkapkan pengalamanya menggunakan KB suntik untuk mencegah kehamilan dini. Kutipan hasil wawancara sebagai berikut: 
“...Saya menggunakan jenis KB suntik tiga bulan, sejak anak ketiga sudah berumur enam bulan. Efek samping dari jenis suntik yang saya rasakan selama ini kepala sakit, leher sakit, berat badan bertambah, tapi itu biasa saja tidak mempengaruhi aktifitas saya sehari-hari. Saya secara pribadi memilih jenis suntik, karena lebih efektif dalam mencegah kehamilan, saya juga merasa KB suntik sudah cocok jadi saya tidak berpikir untuk menggunakan KB jenis lain dan ada pula dukungan penuh suami terhadap penggunaan KB suntik yang saya pakai. Saya terlambat suntik baru 2 kali tapi tidak hamil, jadi untuk cegah hamil saya lebih suka menggunakan jenis suntik, saya pernah berpikir menggunakan KB pil tapi takut kecolongan dan bisa hamil kalau tidak rutin minum pil..."

Selain itu diungkapkan pula oleh Ibu Mersi tentang keefektifan metode suntik dalam mencegah kehamilan dini, seperti pada kutipan hasil wawancara berikut:

“...Saya memakai KB suntik tiga bulan, dari anak berusia 40 hari hingga saat ini. Saya merasa biasa saja, tidak ada efek samping. Menurut saya jenis suntik lebih baik dari jenis lain, dan suami saya sangat setuju saya menggunakan KB suntik, dan tidak berpikir untuk pindah ke jenis lain. Tidak mau menggunakan pil, karena takut kelupaan minum pil dan bisa mendatangkan kehamilan dini. Dan saya rencana untuk melepas suntik jika anak sudah berusia lebih dari 3 tahun..."

Adapun pengalaman lain yang diungkapkan oleh Ibu Julia tentang keefektifan penggunaan metode suntikan dalam kutipan hasil wawancara berikut:

“...Awalnya saya menggunakan metode alamiah dengan menghitung masa subur namun, ternyata kurang efektif sehingga anak kami sekarang sudah lima orang. Dari pengalaman ini saya bersama suami memilih untuk menggunakan metode KB dan yang saya gunakan sekarang adalah metode suntik tiga bulan sekali. Efek yang saya rasakan pertama kali adalah pusing-pusing, malas dan ingin tidur-tiduran, tetapi sekarang sudah tidak lagi hanya berat badan cukup bertambah tapi saya merasakan biasa saja. Saya tidak ingin menggantikan metode lain karena saya sudah merasa nyaman. Saya pernah ditawarkan petugas kesehatan untuk pakai susuk namun, saya tidak mau karena sepertinya suntik lebih cocok dan menurut saya suntikan sangat baik untuk mencegah kehamilan sehingga sampai sekarang saya belum hamil lagi..."

Dari hasil penelitian dapat diketahui bahwa metode suntik dalam MKJP pada Puskesmas Sasi dinilai efektif dalam mencegah kehamilan dini. Uraian para informan bahwa terdapat beberapa efek samping dalam penggunaan metode suntikan seperti penambahan berat badan, haid tidak lancar bahkan tidak mengalami haid selama masa suntik dan sering mengalami pusing atau sakit kepala namun, metode ini dinilai cukup efektif dalam menjarangkan kehamilan karena salah satu cara kerja dari metode suntikan adalah menyebabkan pengurangan fertilisasi pada rahim wanita.

\subsection{Metode Implan KB}

Salah satu metode modern yang digunakan oleh akseptor KB aktif adalah metode implan. Metode ini dikenal juga dengan istilah metode susuk, yakni penggunaan Alat Kontrasepsi Bawah Kulit (AKBK) yang terbuat dari bahan silastik dengan cara disusukannya di bawah kulit akseptor seperti di lengan dan dapat secara efektif menghindari terjadinya pembuahan dalam rahim kurang lebih tiga tahun masa produktifnya. Ada beberapa jenis implan di bawah kulit seperti norplan, implanon dan jadena. Banyak wanita yang memilih metode ini dengan berbagai alasan seperti kesibukan wanita karier, takut akan kehamilan dini dan menjaga jarak karena memiliki anak lebih dari dua. Adapun kutipan hasil wawancara dengan Ibu Getrudis sebagai berikut:

“...Saya menggunakan metode susuk sejak bulan Januari 2021, kini anak saya sudah berusia satu tahun dua bulan. Selama masa pemakaian saya merasa cocok, walaupun baru pertama pakai, hanya efek samping yang saya rasakan tidak haid sampai sekarang namun, saya tidak merasa masalah dalam bersenggama dan menurut saya tidak ada pengaruhnya ke kehamilan dini, karena cara kerjanya untuk mencegah kehamilan, jadi saya memakai susuk juga peluang kecil dan tidak akan hamil sampai 3 tahun. Saya hanya kontrol satu minggu untuk melepas perban luka, jadi tidak ada masalah dengan penggunaan metode implan ini..."

Selain itu diungkapkan juga oleh Ibu Veronika tentang keefektifan penggunaan metode implan dalam kutipan hasil wawancara berikut: 
“...Saya menggunakan KB jenis susuk, untuk masa waktu tiga tahun setelah itu baru dilepas. Pemasangan pertama anak berusia dua tahun, dan tidak ada efek samping yang signifikan seperti berat badan naik, namun tidak terganggu dalam bersenggama, menurut saya pemasangan KB jenis susuk lebih efektif dibandingkan dengan jenis lain. Saya tidak mau menggunakan suntikan karena takut terlambat suntik bisa terjadi hamil, jadi saya lebih memilih metode implan karena sangat efektif untuk mencegah kehamilan dini maksimal tiga tahun..."

Keefektifan dari metode implan diungkapkan juga oleh Ibu Santi dalam kutipan hasil wawancara berikut:

“...Saya pertama menggunakan KB suntik, setelah itu ganti ke implan atau susuk, pertama saya pilih suntik, tapi efek samping haid tidak lancar, dan saya lepas suntik selama satu tahun baru dapat anak. Setelah itu saya ganti pake susuk, namun lepas susuk langsung dapat anak. Efek susuk tidak ada, dan dukungan suami penuh artinya sama-sama mau untuk memakai KB. Saya lebih memilih menggunakan susuk, karena haid lancar, dan merasa nyaman atau cocok, dan menurut saya metode susuk lebih bagus untuk pencegahan kehamilan dini, dan saya rencana untuk tetap menggunakan susuk..."

Hal senada diungkapkan juga oleh Ibu Maria B., yang menjadi peserta KB pada Puskesmas Sasi seperti dalam kutipan hasil wawancara berikut ini:

“...Saya memiliki seorang putra, dan setelah melahirkan putra saya itu saya langsung menggunakan metode KB implan yang ditanam di bawah kulit lengan. Saya mulai pasang implan bulan Juli tahun 2015, dan kini anak saya sudah enam tahun. Ada efek samping saat pasang pertama seperti pusingpusing, kepala sering sakit, menstruasi tahun pertama tidak teratur. Saya pasang dari tahun 2015-2018 saya buka karena melanjutkan studi di Makassar karena takut mengganggu studi. Terakhir pasang lagi sampai sekarang. Saya tidak merasa ada efek samping dalam bersenggama karena susuk itu terletak di bawah lengan. Saya merasa cocok saja dengan penggunaan susuk jika dibandingan jenis lain seperti IUD, rasa takut dan tidak nyaman. Sekarang saya sudah buka karena masih mengiginkan ada anak lagi. Saya pakai yang tiga tahun yang pertama dan yang kedua baru dibuka kembali karena menginginkan anak lagi. Saya lebih memilih susuk saja dibandingkan jenis lain, takut salah hitung bisa cepat hamil atau efek samping lainnya..."

Dari hasil wawancara di atas, para informan menjelaskan bahwa metode implan atau yang dikenal dengan metode susuk lengan merupakan salah satu metode modern yang diterapkan pula di Puskesmas Sasi bagi para akseptor KB aktifnya. Pengalaman para informan menunjukan bahwa metode implan cukup memberikan kenyamanan dalam pencegahan kehamilan dini. Selain itu, metode ini tidak memiliki efek samping yang signifikan dibandingkan dengan metode suntikan karena tidak harus rutin untuk disuntik secara berkala dan masa haid pada wanita datang secara teratur, serta tidak memiliki efek samping ketika bersenggama. Hal ini menunjukkan bahwa cukup efektif metode susuk dalam mencegah kehamilan dini terutama bagi para PASUTRI yang tidak ingin memiliki banyak anak.

\subsection{Metode Pil KB}

Metode pil merupakan salah satu jenis MKJP yang diminati oleh para wanita usia subur pasca menikah yang harus diminum secara rutin guna menghindari terjadinya kehamilan. Pil KB juga memiliki cara kerja hampir serupa dengan metode suntikan yakni mencegah jalannya sperma ke rahim dan adanya pengentalan lendir serviks sehingga tidak dengan mudah terjadinya pembuahan. Metode pil sangat beresiko terhadap kehamilan dini apabila kurangnya kedisiplinan akseptor dalam mengkonsumsi pil secara rutin. Seperti dalam kutipan wawancara berikut dengan Ibu Yasinta sebagai berikut:

“...Saya cocok dengan metode pil, saya menggunakannya sejak anak ke tiga, dan saya lepas menggunakan KB tidak pakai suntik dan sekarang saya pakai pil. Efek suntik tidak haid sehingga saya ganti ke pil, supaya bisa haid. Saya pakai pil sejak anak ke empat umur lima tahun, dan harus minum setiap malam. Dan saya berusaha untuk tidak lupa minum, dan saya merasa lebih bagus pakai pil dibanding metode lain, hanya kalau salah minum bisa hamil. Badan naik drastis, tapi tidak terdapat pengeluhan saat bersenggama, dan ini merupakan kemauan dari suami dan istri. Menurut saya, pakai pil lebih bagus dari metode lain, dan saya tidak ingin berpindah ke metode lain. Saya akan minum sampai tidak dapat melahirkan lagi karena kami tidak mau ada anak lagi...” 
Selain itu ada pula kutipan hasil wawancara dengan informan lainnya yakni Ibu Wasti yang mengungkapkan pengalamannya ketika menggunakan metode pil MKJP sebagai berikut:

"...Saya pertama pake suntik, tapi menstruasi tidak lancar selama satu setengah tahun, jadi saya ganti pil. Saya pake pil sudah lima bulan, dan saya merasakan haid lancar, dan tidak ada efek samping dari pil. Dukungan penuh dari suami karena tidak ada efek samping lainnya atau pada saat bersenggama, dan saya rencana pakai pil untuk sementara waktu, saya takut pakai susuk dan menurut saya untuk mencegah hamil lebih nyaman dan cocok pake pil karena haid lancar, tidak ada efek samping, dan selama ini saya selalu ingat untuk minum rutin, walaupun tidak bersenggama, dan saya sementara ini tetap mau pakai pil, saya tidak mau pake metode lain karena ada rasa takut terhadap masuknya benda asing dalam tubuh seperti benda selang, karet yang bisa berpengaruh pada tubuh..."

Adapun ungkapan lain tentang efektifnya metode pil dalam mencegah kehamilan dini yang dijelaskan oleh Ibu Dafrosa seperti dalam kutipan hasil wawancara berikut:

“...Menurut saya, KB pil merupakan metode yang tepat dalam pencegahan kehamilan dini. Saya pernah menggunakan metode suntik tiga bulan pasca melahirkan anak pertama namun, karena merasa harus suntik setiap tiga bulan dan saya takut terhadap jarum suntik, maka saya beralih ke pil. Selama minum pil, saya tidak merasakan efek samping dan saya merasa KB dengan metode pil cukup baik untuk mencegah kehamilan dini, hanya khawatirnya jika tidak minum rutin maka bisa terjadi kehamilan. Saya rasakan hal tersebut karena anak kedua dan ketiga, waktu itu saya tidak minum pil KB makanya kecolongan hamil jarak dekat."

Metode pil KB termasuk dalam MKJP yang diterpakan juga di Puskesmas Sasi Kota Kefamenanu. Metode ini termasuk metode modern yang sangat kecil efek sampingnya namun, cukup beresiko tinggi dalam mencegah kehamilan dini. Pengalaman beberapa informan terkait penggunaan metode pil KB selama ini menunjukkan bahwa ada kekhawatiran terhadap kehamilan dini jika tidak disiplin atau adanya kelalaian dalam mengonsumsi pil KB. Di lain pihak, ada pula informan yang mengungkapkan bahwa pil KB termasuk salah satu metode KB untuk mencegah kehamilan dini, tergantung dari diri pribadi para akseptor untuk rutin dan teliti dalam menggunakannya. Dengan demikian, dapat disimpulkan bahwa metode pil KB cukup beresiko dalam kehamilan dini jika akseptor kurang disiplin mengontrol penggunaannya secara rutin.

\subsection{Metode IUD}

Metode IUD merupakan salah satu MKJP atau metode modern yang dikenal dengan istilah metode spiral. Metode ini merupakan jenis alat kontrasepsi dalam rahim (AKDR) yang terbuat dari tembaga bercampur perak dan dimasukan dalam rongga rahim selama kurang lebih sepuluh tahun. Cara kerja dari metode IUD adalah mencegah masuknya sperma ke dalam rahim dan mengurangi kesuburan wanita serta menghambat pertemuan sel sperma dan sel telur sehingga tidak terjadinya pembuahan. Sebagian PASUTRI di wilayah Puskesmas Sasi menggunakan metode ini seperti dalam kutipan hasil wawancara dengan Ibu Christina....

“...Saya menggunakan KB jenis spiral, sejak anak ketiga dan sudah habis masa produktif karena sudah dipakai dari tahun 2012. Saya sementara mau lepas tapi ada bermaslah yakni benang tidak kelihatan dan saya belum kontrol lagi. Efek samping tidak terlalu hanya sering-sering merasa nyeri kalau bekerja berat. Dan pusing pada awal-awal pemasangan dan banyak haid tapi sekarang tidak lagi. Agak terganggu sedikit kalau bersenggama. Menurut saya spiral cukup efektif dalam mencegah kehamilan dan saya dari awal menggunakan jenis ini jadi merasa lebih baik saja...”

Informasi lain diperoleh dari Ibu Dolfiana tentang efektifnya penggunaan metode IUD seperti pada kutipan hasil wawancara berikut ini:

"...Saya memakai alat kontrasepsi jenis IUD atau spiral, sejak operasi anak ketiga di bulan Maret 2021 dan baru tujuh bulan, alasan saya karena jarak anak terlalu dekat dan saya baru berusia dua puluh empat tahun, sehingga harus pake spiral dan adanya dukungan suami dan keluarga setuju untuk saya gunakan spiral. Dan nanti sekitar sepuluh tahun baru dibuka, dan tidak ada efek samping lainnya hanya berat badan bertambah. Saya tidak mau menggunakan jenis lain, karena takut hamil lagi jadi pakai IUD untuk bisa jaga jarak kehamilan..." 
Hasil penelitian menunjukkan bahwa metode modern dengan jenis IUD ini sangat efektif dalam mencegah kehamilan dini, karena cara kerja metode IUD adalah mencegah terjadinya pembuahan dalam rahim selama kurun waktu sepuluh tahun. Biasanya pemasangan IUD terjadi pada wanita yang tidak ingin memiliki anak lagi sampai dengan masa sepuluh tahun namun, di sisi lain terdapat efek samping yang beresiko tinggi pada keselamatan nyawa pengguna jenis IUD karena metode IUD harus dipasangkan pada rongga rahim. Kecemasan seorang akseptor KB terhadap pemasangan IUD adalah terjadi ketidakcocokan dan bisa mendatangkan pendarahan dan penyakit penyerta lainnya seperti berat badan bertambah atau sebaliknya dan terjadinya masalah lainnya pada rahim wanita yang berhubungan dengan pemasangan IUD.

\subsection{Metode Tubektomi dan Vasektomi}

Metode tubektomi (MOW) merupakan metode yang dinilai sangat efektif dan bersifat permanen atau tetap karena melakukan tindakan pembedahan secara steril untuk pemotongan saluran sel telur sehingga tidak dapat dibuahi oleh sel sperma. Tindakan ini dinilai cukup sederhana, dan sering dilakukan oleh wanita pasca melahirkan anak yang banyak dan tidak ingin memiliki anak lagi diusia kurang lebih tiga puluh lima tahun. Cara kerjanya adalah tindakan operasi pemotongan dan pemasangan cincin pada saluran sel telur yang bertujuan menghalangi sel sperma bertemu dengan sel telur. Sedangkan metode vasektomi (MOP) merupakan jenis metode modern atau metode KB mantap pada laki-laki yang bertujuan pengikatan atau pemotongan jalannya sel sperma agar tidak keluar dari buah zakar laki-laki. Metode ini kurang diminati oleh laki-laki, walaupun tindakan ini dinilai sangat efektif dan tidak memiliki efek samping lainnya yang bersifat permanen.

Pada Puskesmas Sasi tidak ditemukan adanya data riil tentang akseptor KB aktif yang memilih menggunakan metode tubektomi maupun metode vasektomi, walaupun sebenarnya kedua metode ini dinilai cukup efektif dan sederhana namun, peneliti tidak menemukan adanya akseptor KB aktif yang menggunakan kedua metode tersebut.

Tabel 2. Ringkasan Hasil Penelitian

\begin{tabular}{cl}
\hline Metode & \multicolumn{1}{c}{ Ringkasan } \\
\hline Suntik KB & $\begin{array}{l}\text { Metode suntik dalam MKJP lebih diminati oleh akspetor KB aktif di } \\
\text { wilayah Puskesmas Sasi Kota Kefamenanu. Metode ini dinilai cukup } \\
\text { efektif dalam menjarangkan kehamilan. Jenis suntikan 1 bulan dan 3 } \\
\text { bulan. } \\
\text { Metode implan memberikan kenyamanan dalam pencegahan } \\
\text { kehamilan dini. Masa penggunaannya kurang lebih 3 tahun. }\end{array}$ \\
Implan KB \\
Petode ini dapat mencegah kehamilan dini namun, tergantung dari \\
diri pribadi para akseptor untuk rutin dan teliti dalam \\
mengonsumsinya setiap hari. \\
IUD & $\begin{array}{l}\text { Metode IUD sangat efektif dalam mencegah kehamilan dini selama } \\
\text { kurun waktu 10 tahun pemakaiannya. }\end{array}$ \\
MOW & $\begin{array}{l}\text { Metode MOW dan MOP merupakan metode yang dinilai sangat } \\
\text { efektif dan bersifat permanen atau tetap karena melakukan tindakan } \\
\text { pembedahan secara steril baik pada wanita maupun pria. }\end{array}$ \\
MOP &
\end{tabular}

\section{MINAT AKSEPTOR KB AKTIF DALAM MENGGUNAKAN MKJP}

Alat kontrasepsi modern atau MKJP merupakan sarana yang dinilai cukup efektif dalam mencegah kehamilan dini karena dapat meminimalisir terjadinya pembuahan pada rahim wanita. Berbagai metode kontrasepsi yang ditawarkan oleh sarana kesehatan menjadi solusi bagi setiap PASUTRI yang berkeinginan untuk tidak memiliki anak lagi baik dalam jangka waktu tertentu maupun secara permanen. Adapun tujuan dari pemanfaatan MKJP baik secara berkala ataupun rutin adalah untuk memberikan keselamatan pada ibu pasca melahirkan maupun anak yang disebabkan melahirkan pada usia dini, atau 
jarak kelahiran antara anak yang telah lahir dan yang akan lahir cukup dekat atau dapat terjadi pada wanita yang melahirkan diusia lanjut.

Seorang akseptor KB aktif, keluarga dan terlebih petugas kesehatan di Puskesmas Sasi atau juga di tempat lainnya memiliki peran penting dalam meningkatkan kesadaran masyarakat untuk menggunakan metode kontrasepsi yang sesuai. Terdapat juga wanita yang takut menggunakan MKJP karena pengaruh efek samping dari berbagai metode yang ditawarkan. Minat menggunakan MKJP bukan menjadi hal yang mudah bagi setiap orang, karena setiap efek yang timbul dari reaksi MKJP akan dirasakan secara langsung oleh para PASUTRI. Hal ini yang menjadi kendala setiap orang merasa takut ataupun cemas dalam menggunakan MKJP. Sebenarnya MKJP seharusnya disosialisasikan secara berkala guna memberikan pengetahuan dan pemahaman secara luas tentang efektifnya penggunaan MKJP dalam mencegah kehamilan dini terutama bagi para PASUTRI usia produktif yang memiliki tingkat kesibukan cukup tinggi. Selain itu, dengan adanya kesadaran masyarakat untuk menggunakan MKJP dapat berdampak pada pengaturan kehamilan sedemikian rupa agar terciptanya keluarga berencana yang sejahtera terutama kehidupan anak lebih terjamin dan terencana.

\section{KESIMPULAN}

Metode Kontrasepsi Jangka Panjang (MKJP) atau metode modern yang digunakan oleh akseptor KB aktif di Puskesmas Sasi Kota Kefamenanu pada tahun 2021 terdiri dari metode suntikan KB, metode implan, metode pil, dan metode IUD, sedangkan metode vasektomi (MOP) dan tubektomi (MOW) yang juga termasuk dalam metode modern tidak ditemukan di Puskesmas Sasi. Berdasarkan hasil penelitian dapat disimpulkan bahwa MKJP dinilai efektif dalam mencegah terjadinya kehamilan dini karena cara kerja dari metode-metode tersebut pada dasarnya adalah mengurangi fertilisasi atau kesuburan wanita dan menghalangi pertemuan antara sel sperma dan sel telur pada rongga rahim sehingga tidak terjadinya pembuahan. Masing-masing metode tersebut memiliki tingkat kerja yang berbeda-beda. Selain memiliki keefektifan dalam mencegah kehamilan dini, MKJP juga memiliki efek samping yang dapat dialami oleh setiap akseptornya namun, tingkat resiko tergantung dari kedisiplinan pengontrolan secara berkala dari setiap akseptor $\mathrm{KB}$.

\section{DAFTAR PUSTAKA}

Aldila, D., \& Damayanti, R. (2019). Persepsi Terhadap Alat Kontrasepsi Dengan Keputusan Penggunaanmkjp Dan Nonmkjp. Hasanuddin Journal of Midwifery., 1(2), 58-65.

Ari, A., \& Trisnawati, I. (2016). Hubungan pengetahuan, sikap dan budaya akseptor kb terhadap pemilihan metode akdr di wilayah kerja puskesmas Anggadita kabupaten Karawang. Jurnal Kebidanan Unimus, 5(1), 11-17.

Aryati, S., Sukamdi, S., \& Widyastuti, D. (2019). Faktor-Faktor Yang Mempengaruhi Pemilihan Metodekontrasepsi (Kasusu Di Kecamatan Seberang Ulu I Kota Palembang). Majalah Geografi Indonesia, 33(1), 79. https://doi.org/10.22146/mgi.35474

Budiarti, I., Nuryani, D. D., \& Hidayat, R. (2017). Determinan Penggunaan Metode Kontrasepsi Jangka Panjang (MKJP) pada Akseptor KB. Jurnal Kesehatan, 8(2), 22. https://doi.org/10.26630/jk.v8i2.490

Dukcapil, D. (2021). Distribusi Penduduk Indonesia Per Juni 2021. Direktorat Jenderal Kependudukan Dan Pencatatan Sipil Kementerian Dalam Negeri RI.

Ernawati, S. (2016). Faktor yang Memengaruhi Keluarga Berencana (KB) Pria dengan Paritisipasi Pria dalam Keluarga Berencana di Wilayah Kerja Puskesmas Sedayu II. Jurnal Ners Dan Kebidanan Indonesia, 4(2), 109. https://doi.org/10.21927/jnki.2016.4(2).109-116

Farina, A. M. N. F., \& Susilowati, E. (2017). Analisis Faktor-Faktor Yang Berhubungan Dengan Pemilihan Alat Kontrasepsi KB suntik oleh Akseptor KB di Desa Kedungglugu Kabupaten Nganjuk. In repository.poltekkespim.ac.id: Vol.

Laili, U., \& Masruroh, N. (2018). Penentuan Jarak Kehamilan Pada Pasangan Usia Subur. Jurnal Kesehatan Al-Irsyad, XI, Nomor, 53. 
Nasution, P., \& Naibaho, E. (2018). Analisis Faktor Untuk Mengetahui Hambatan dalam Penggunaan Kontrasepsi Implan di Desa Suka Maju Kecamatan Sunggal Kabupaten Deli Serdang. Jurnal Bidan Komunitas, 1(1), 26. https://doi.org/10.33085/jbk.v1i1.3916

Nugraheny, D. E. (2020). Data Kependudukan 2020. Kompas.Com. -

Purwanti, S., \& Trisnawati, Y. (2016). Pengaruh Umur dan Jarak Kehamilan Terhadap Kejadian Perdarahan Karena Atonia Uteri. Jurnal Publikasi Kebidanan Akbid YLPP Purwokerto, 5(3), 12 19. http://ojs.akbidylpp.ac.id/index.php/Prada/article/download/164/136

Rendys, S., Nunik, P., \& ... (2017). Faktor yang Memengaruhi Pemilihan Metode Kontrasepsi. Jurnal Biometrika Dan Kependudukan, 5(2), 91. https://doi.org/10.20473/jbk.v5i2.2016.91-98

Sari, P., Yerizel, E., \& Serudji, J. (2018). Artikel Penelitian Perbedaan Kadar Aldosteron dan Tekanan Darah pada Akseptor KB Pil Kombinasi Berdasarkan Lama Pemakaian Kontrasepsi. 7(2), 154159.

Sugiyono. (2015). Metode Penelitian Manajemen. Alfabeta.

Sugiyono. (2017). Metode Penelitian Kuantitatif, Kualitatif, dan R\&D. Alfabeta.

Susanti, E. T., Sari, H. L., Keperawatan, A., Bhakti, K., \& Magelang, N. (2020). Pendidikan Kesehatan Tentang Jenis-Jenis Alat Kontrasepsi Terhadap Pemilihan Alat Kontrasepsi. 9(1), 53-57.

Weni, L., Yuwono, M., \& Idris, H. (2019). Determinan Pemilihan Metode Kontrasepsi Jangka Panjang Pada Akseptor KB Aktif di Puskesmas Pedamaran. Scientific Periodical of Public Health and Coastal Health, 1, nomor 1, 2.

Wulandari, Y., Taufik, M., \& Ridha, A. (2016). Faktor-Faktor Yang Mempengaruhi Penggunaan Metode Kontrasepsi Jangka Panjang (MKJP) Pada Pasangan Usia Subur di Kabupaten Sambas. Repository.Unmuhpnk.Ac.Id. 